\title{
The Rise of Judicial Activism in New Zealand
}

\author{
James Allan
}

\begin{abstract}
HOULD judges unswervingly follow the legislature's clearly worded enactments S and their own past decisions? Or should they modify such legislation to ensure that it is fair and appropriate? The question is certainly not new. Shakespeare, in The Merchant of Venice (IV.i.212-19), raises it in dramatic fashion when he has Antonio forfeit his bond of a pound of flesh to Shylock. Must Antonio pay, and so die? To avoid this result, Bassanio beseeches the judge (who is Portia in disguise) to:
\end{abstract}

Wrest once the law to your authority:

To do a great right, do a little wrong,

And curb this cruel devil of his will.

But Portia immediately replies:

It must not be. There is no power in Venice

Can alter a decree established.

'Twill be recorded for a precedent,

And many an error by the same example

Will rush into the state. It cannot be.

In recent decades, judges throughout the common law world seem to have been tending towards Bassanio's way of thinking. The Canadian judiciary ${ }_{1}$ provides probably the best example of what is generally called 'judicial activism'. But its New Zealand counterpart has been almost as inclined to do 'great rights'.

Until recently, New Zealand's judiciary followed the traditional British practice of interpretation. Statutes were read in a fairly literal way. Precedents were considered binding, except in rare cases, and the rules they articulated were only exceptionally broadened, narrowed or eliminated. Parliament was viewed as the legitimate source of law reform. Most judges saw themselves as independent arbiters

${ }^{1}$ See, for example, Mandel (1989).

James Allan is Lecturer in Law at the University of Otago. 
and appliers of rules that had either been laid down ${ }_{2}$ by parliament or slowly evolved (to deal with particular disputes) in past precedents.

According to Professor John Smillie (1996:258),

From the early 1980 s it seems to have become accepted, particularly by members of the Court of Appeal, that New Zealand society is unique in important respects and is changing rapidly, and that the inherited common law no longer reflects the current needs, values and aspirations of our community. Furthermore, it is neither necessary nor appropriate to rely on Parliament to make the necessary changes; the judges must accept direct responsibility for adapting and developing the law to meet current needs.

As evidence of this change, Smillie cites a host of extra-judicial writings and comments by New Zealand's highest judges to the effect that judges need 'to reflect contemporary thinking', to avoid 'abdicating their responsibility to keep the law abreast of the times', 'to give effect to reasonable expectations', to aim for 'fairness' (though not for mere 'popularity, which can be a most dangerous criterion'), and to find the most 'efficient solution'. As well, Smillie cites many cases in which the judges have moved away from more or less clear rules laid down in legislation or leading judicial precedents towards 'more abstract standards which leave judges with wide practical discretion at their point of application' (1996:262). In effect, the New Zealand courts of late have been ever more willing to import considerations of equity and fairness into the civil law. The inevitable result - indeed, the result desired by the judges - has been an increase in judicial discretion and a reduction in the certainty of the law. Lord Cooke of Thorndon, the former President of the New Zealand Court of Appeal, has dismissed considerations of certainty in the law: 'The appeal to certainty in the law can be a badge of sharp dealing, or of an ostensibly reluctant readiness to take advantage of the fruits of sharp dealing' (quoted in Smillie, 1996:260).

Moreover, in the exercise of this discretion, and as evidence of the 'contemporary values' the judges purport to be finding, they sometimes rely upon statutory provisions, international agreements and even recommendations of law reform bodies as bases for developing the law in the desired direction. But when such materials point in a direction that the judges do not approve of, they are often simply ignored (Smillie, 1996:261).

\section{Interpreting the Bill of Rights Act 1990}

The trend towards judicial activism that Smillie notes in tort law and contract law is even more pronounced in public law. This is very likely due largely to the enactment of New Zealand's Bill of Rights Act 1990 which, despite its specifically and deliberately limited status as an ordinary statute, has been used by the judiciary to

${ }^{2}$ See, for example, Ross v McCarthy [1970] NZLR 449. 
strengthen its hand against the legislature. This Act, applying only to legislative, executive, or judicial acts or other legally mandated acts of a public nature, has three key operative sections, which read as follows:

4. Other enactments not affected - No court shall, in relation to any enactment (whether passed or made before or after the commencement of this Bill of Rights),

(a) Hold any provision of the enactment to be impliedly repealed or revoked, or to be in any way invalid or ineffective; or

(b) Decline to apply any provision of the enactment - by reason only that the provision is inconsistent with any provision of this Bill of Rights.

5. Justified limitations - Subject to section 4 of this Bill of Rights, the rights and freedoms contained in this Bill of Rights may be subject only to such reasonable limits prescribed by law as can be demonstrably justified in a free and democratic society.

6. Interpretation consistent with Bill of Rights to be preferred - Wherever an enactment can be given a meaning that is consistent with the rights and freedoms contained in this Bill of Rights, that meaning shall be preferred to any other meaning.

The previous Labour government had proposed an entrenched, supreme Bill of Rights that would have empowered the courts to redress violations of rights by granting such remedies as the courts considered appropriate and just in the circumstances. It would thus have greatly increased the powers and scope for judicial discretion. But opposition to it was so strong that the eventual 1990 version was legislated only with great difficulty. Indeed, the insertion of the clause in s.4, 'other enactments (both those passed before and after this Act) not affected', on the face of it rendered the New Zealand Bill of Rights Act 1990 less than an ordinary statute, since ordinary statutes overrule others of an earlier date when there is an inconsistency. As it was, the then Prime Minister, in moving the Bill's second reading, had to state that the 'Bill creates no new legal remedies for courts to grant. The judges will continue to have the same legal remedies as they have now, irrespective of whether the Bill of Rights is an issue'.

Given this opposition to a full-blooded Bill of Rights, and the enfeebled version ultimately enacted, it might have been expected that New Zealand judges would take anything but an activist stance when it came to interpreting the new Bill of Rights Act 1990. The reality has proven to be otherwise.

${ }^{3}$ (1990) 510 New Zealand Parliamentary Debates 3450. 
A recent New Zealand Court of Appeal decision serves to make the point. In Simpson v Attomey-General (Baigent's Case), it was held, by a 4 to 1 majority, that a breach of the Bill of Rights Act gives rise to a new civil cause of action in public law and may attract a remedy in the form of monetary compensation. In other words, although the 1990 Act contained no provision for remedies (indeed, the remedies provision in the earlier, full-blooded draft had been deliberately removed), and although that Act had been thought not to override other inconsistent statutes, the Court of Appeal created ad hoc a previously unheard-of public law remedy sounding in the Bill of Rights. In creating this new special regime of public civil liability, whose scope remains highly uncertain, the court simply ignored or avoided existing statutory immunities while greatly widening the legal ramifications of the Bill of Rights.

The Baigent appeal arose out of an action against the Attorney-General in respect of acts of the police. The action was still at an interlocutory stage and the question before the court was whether the facts, as pleaded, disclosed any cause of action, particularly in the light of the Crown's reliance on a strongly worded statutory immunity. The Court of Appeal held that various causes of action, including trespass, could stand. But the real importance of the case lay in the majority's creation of an independent civil claim for infringement of one of the Bill of Rights' rights.

Two obstacles were seen as lying in the path of the creation of such a cause of action. One was the lack of any provision in the Bill of Rights itself for remedies for infringement. The other was the statutory immunity ${ }^{6}$ relied on by the police and Crown. To overcome the former, the majority gave these arguments:

- The Courts must give effect to rights. [This also appeared as the 'civilised society argument', the 'take the generous approach' argument, and the 'rights demand remedies' argument.]

- The history of the legislation is unimportant. Parliament must have intended to give effect to rights.

- The purpose of the legislation is fully revealed by the long title which refers to the International Covenant on Civil and Political Rights and that treaty does have a remedies clause.

- Other jurisdictions provide a remedy when their Bill of Rights' rights are infringed.

- The legal or constitutional form of the enactment is irrelevant.

\footnotetext{
4 [1994] 3 NZLR 667.

${ }^{5}$ For full discussions of Baigent's Case, see Smillic (1994) and Allan (1994).

6

Section 6(5) of the Crown Proceedings Act 1950.
} 
Besides the fact that the first two arguments assume that only judges can really protect people's rights, the whole tenor and reasoning of the majority judgments appear to be to the effect that adopting a Bill of Rights as an ordinary statute makes no difference. Judges, ignoring the legislative history mentioned above, can still use such a Bill of Rights to protect what they see as individuals' 'fundamental' rights. The form or manner in which a Bill of Rights is adopted cannot be relied upon to limit the increase in judicial power which the implementation of a Bill of Rights brings with it. Even a strongly worded operative provision like s.4, aimed at keeping the courts subordinate to parliament, appears to be of limited effect. So the clear effect of the New Zealand judges' reasoning in Baigent is that one cannot (and should not) differentiate either between those Bill of Rights that are entrenched (to make later alteration difficult) and those that are ordinary statutes, or between those that provide for remedies clauses and those that do not.

This case and others have made it apparent that the New Zealand judiciary is prepared to give the Bill of Rights Act an elevated status and influence that its framers explicitly rejected. A corollary of this is that the judges' ability to make social policy on a case-by-case basis has increased markedly, against the backdrop of divining the meaning, in particular cases, of a set of vague, amorphous and broad rights. Judicial power and discretion in public law have substantially increased.

The typical defender of a strong Bill of Rights would argue that basic freedoms cannot be secure in the absence of a justiciable Bill of Rights, since a sovereign and supreme parliament cannot be trusted. But there is no more reason to trust unelected judges who have life tenure than there is to trust elected legislators who do not have life tenure. ${ }^{8}$ There is no evidence that basic freedoms are better protected in the United States or Canada, which have entrenched, justiciable Bills of Rights, than in, for example, Australia, which has no Bill of Rights. Nor would it be possible (in my view) to argue that New Zealand's Bill of Rights Act has somehow, since its adoption in 1990, augmented the freedoms New Zealanders previously enjoyed.

\section{Further Examples of Judicial Activism}

A further recent example of judicial activism takes the form of procedural activism by the courts. In $Z_{v} Z^{9}$, the Court of Appeal had to consider a matrimonial dispute on the question of whether a husband's future earnings were to qualify as matrimonial property. During the course of the hearing, without the consent of the parties, the Court appointed the Auckland Women's Lawyers Association and the Solicitor-General as amici curiae (friends of the court). Subsequently, applications

\footnotetext{
${ }^{7}$ For the New Zealand Court of Appeal's views on the inter-relationship of the operative provisions, see Ministry of Transport v Noort [1992] 3 NZL R 260.

8

See Allan (1996) and Allan and Cullen (1997). The gist of my argument is that claims to the effect that a 'true' democracy does not always equal majoritarianism cannot withstand scrutiny. 9 
were made and allowed for other pressure groups to be represented, though not to be given a public opportunity to make submissions. The Court of Appeal then allowed affidavits to be submitted on an issue upon which the parties had already agreed (that is, the value of the husband's position in a partnership) and which was not part of the order appealed against. Then, to consider this new issue, the Court of Appeal turned itself into the High Court and ordered certain questions of law (which had not been before the High Court in the original appeal from the Family Court) to be removed into the Court of Appeal for argument.

The Court of Appeal claimed that this procedural device was employed 'following consultation with the parties', though the consultation evidently included people not described on the face of the judgment as parties. As well, the push to consider these additional questions appeared to come from these 'non-parties'. As a result of this singular conduct by the Court of Appeal, one commentator on the case was able to ask:

So who can now be confident that if an appeal to the Court of Appeal raises issues which hit the headlines the case will not be redirected by outsiders and by a Court of Appeal which apparently has the power to turn itself into a High Court, ask itself questions it, rather than the parties, wants answered, and then turn itself back into the Court of Appeal and answer them? ${ }^{10}$

In the event the Court of Appeal decided, in a few paragraphs, that the governing Act was clear and that such future earnings did not qualify as matrimonial property. At the same time, however, the Court re-opened the question of the valuation of the husband's partnership and sent the issue back to the High Court (the real one, not the Court of Appeal transformed) for further submissions. Not surprisingly, an appeal to the Privy Council is being pursued.

Other examples of recent judicial activism in New Zealand have to do with judges changing the existing law. One involves the judicial treatment of exemplary damages as a means to overcome perceived injustices in the statutory accident compensation system. Two recent cases suggest that some New Zealand judges are prepared to employ exemplary damages to compensate personal injury victims for losses no longer qualifying under the no-fault accident compensation scheme: that is, to use exemplary damages in a new way to circumvent recently imposed statutory limits on compensation. In addition, employment law decisions by the Employment Court have been made which, in the view of various commentators, ignore the clear intention and meaning of the Employment Contracts Act 1991. The gist of these commentators' gravamen is that the Employment Court is seeking to retain as

\footnotetext{
${ }^{10}$ Editorial [1997] NZLJ 37.

${ }^{1}$ See McLaren Transport Ltd $v$ Somenville [1996] 3 NZIR 424 and $G \vee G$ (HC Auckland, M 535/95, 15 October 1996, CartwrightJ).
} 
much $_{12}$ as possible of the old labour law regime, whatever the new Act may clearly state.

Yet this new-found willingness on the part of judges to 'wrest the law to their authority' has been widely welcomed, indeed celebrated. In April 1997, Lord Cooke of Thorndon ${ }^{13}$ was feted by the New Zealand legal establishment (with judges from abroad also speaking) at a commemorative conference honouring his judicial influence and outlook. The title of the conference was 'The Struggle for Simplicity: The Cooke Era in New Zealand Law'. Its main thrust, manifest in the judicial approach of Lord Cooke, was to the effect that judges should aim directly for fairness, relying on broad notions of shared social values and conscious value judgments, rather than merely enforcing already laid down rules.

\section{Problems with Judicial Activism}

Portia's endorsement of judicial restraint and the need for judges to follow and apply clear rules would today be described as 'normative positivism', the doctrine that legal decision-making by judges should be made with the least possible moral and discretionary input by the judges themselves.

No one argues that rules laid down in legislation or leading judicial precedents always give answers to factual disputes. The nature of language is such that a penumbra of doubt or open texture or indeterminacy of meaning surrounds all rules. $^{15}$ Inevitably, therefore, judges have some discretion and have to make law in some cases. The normative positivist argues, however, that such discretion (and direct appeals to moral considerations) should be limited; relatively less judicial discretion is better than relatively more; pervasive judicial discretion and resort to morality have bad consequences.

There are many arguments in favour of the proposition that judges should only very rarely act as quasi-legislators. Such behaviour politicises the judiciary and obstructs government, and is usually based on an inherently vague, amorphous and ambiguous bill of rights. But it is the anti-majoritarianism implicit in judicial activism that is its most serious fault. Judges are not elected and have no democratic legitimacy. On what basis, then, do they purport to have any warrant for deliberate social policy-making and the imposition of 'fair' outcomes? It is one thing to concede that judges inevitably have to make law in the penumbra of the rules' uncer-

${ }^{12}$ See, for example, Brighouse Ltd v Bilderbeck [1994] 2 ERNZ 243 (CA) and Smith v Radio i Ltd [1995] 1 ERNZ 281. For an extremely robust attack on the Employment Court in New Zealand, and its interpretation of the Employment Contracts Act 1991, see Howard (1995).

${ }^{13}$ The Court of Appeal is New Zealand's highest domestic court As appeals to the Privy Council in London are still allowed, and about half a dozen full appeals are heard there each year, the Court of Appeal is not, strictly speaking, New Zealand's highest court. Lord Cooke, formerly Sir Robin Cooke, was the President of the Court of Appeal and its dominant figure over the past 15 years or so, until his retirement and ennoblement in 1996.

${ }^{14}$ For a defence of normative positivism, see Waldron (1992) and Allan (1997).

15 .

The classic exposition of normative positivism is given by Hart (1994), especially chapter 7 . 
tainty. It is quite another for judges to set out 'to do great rights', to ignore even clear rules so as to impose the outcome they perceive to be 'fair'.

Another difficulty with appeals to 'fairness' and 'justice' is that such notions are highly subjective: one man's fairness is another man's oppression. The standard of 'fairness' is personal and intuitive. Nor is there any settled way to demonstrate or determine whose views are correct. Hence, any claim of a 'fair' outcome or decision reflects only the claimant's own moral convictions. In this situation, the democrat favours "letting the numbers count ${ }^{17}$ as a way of resolving major social policy disputes, even about what may or may not be deemed fair.

Normative positivism, the rule-based approach to adjudication, is attractive also because it produces more certainty about the likely outcome of cases. Where rules are followed and operate to limit the discretion of judges (both by reducing the number of facts the judge can take into account and by precluding a direct appeal to the merits and relative worth of particular outcomes), results are more predictable and certain. Professor Smillie (1996:266) is surely correct to argue that:

There can be no doubt that a judicial philosophy based on the pursuit of individual faimess attracts serious disadvantages. Obviously it makes the law] less certain and predictable. Indeed, that is its very aim and function. So in an increasing range of situations ordinary people and their professional advisers are left unsure as to the nature of their obligations and the consequences that will follow in the event of breach ... [L]itigation becomes more complex, protracted and costly ... Hearings last longer, litigants face longer delays in getting to trial, and the incentive to appeal an adverse decision becomes stronger.

Moreover, although judicial law-making assuredly benefits lawyers, in most cases the 'results actually achieved by the fairness approach [do not seem] demonstrably "fairer" and more sensible than those dictated by strict application of traditional rules' (Smillie, 1996:266).

A further disadvantage of judicial activism, especially when it is bolstered by a Bill of Rights as it is in New Zealand, is that it fosters a tendency in legislatures to abdicate tough decisions to the judiciary. Legislators, who see the judiciary intruding ever more into social policy-making and who see little benefit in attacking either the judges themselves or the Bill of Rights, have an incentive simply to leave tough choices to the courts. Why go through the compromise-filled process of making legislation when the courts may ignore or override it?

\footnotetext{
${ }^{16}$ Smillie argues that Lord Cooke's appeal to fairness 'represents an extraordinarily arrogant philosophy'. He notes that 'Lord Cooke has explained that the ideal of fairness "is independent of religious belief, yet it can find inspiration in Christian teaching ..." (citation omitted), and judges that Lord Cooke's faimess criterion displays 'a strongly paternalistic, communitarian sense' (1996:261).

17

For an excellent rebuttal of the purported democratic credentials of strong judicial review (in which judges have the last word), see Waldron (1994).
} 
From about the mid-1980s, but especially since 1990 , the New Zealand parliament has taken to passing Acts which include sections that invite, even instruct, the judges to give priority to vague, amorphous notions like the principles of the Treaty of Waitangi' or 'proper respect for cultural, ethnic and ethical beliefs' or 'the intrinsic value of ecosystems' or even 'the maintenance and enhancement of amenity values'. It has also passed legislation to set up a Privacy Commissioner, a Human Rights Commissioner, and a Children's Commissioner and given all of them, on the basis of only the most general and indeterminate of articulated principles, wide powers to make multifarious decisions that affect citizens.

In these ways, the executive and the legislature have contributed (though not in the case of the Bill of Rights) to a political and legal climate that has made it easier for judges to embrace judicial activism. But the public has generally not appreciated this.

\section{Conclusion}

Judicial activism is a fact of life in New Zealand today. In my view, it will have undesirable long-term consequences. Portia was right: there is a price to be paid when judges 'wrest the law to their authority' and aim 'to do great rights'. That price will be paid in the coin of a more uncertain legal system and a weakened democracy.

Meanwhile, those who believe that judges need more room for creativity and are unduly constrained when required to apply clear rules should recall that judges already have plenty of room to manoeuvre without also disregarding statutes and established precedents. The older, traditional approach to adjudication functioned well for a long time. It still commands widespread support. The rejection of judicial activism would not, therefore, require the articulation of some novel or revolutionary alternative.

\section{References}

Allan, J. (1994), 'Speaking with the Tongues of Angels', New Zealand Bill of Rights Bulletin 1: 2-7.

(1996), 'Bills of Rights and Judicial Power - A Liberal's Quandary', Oxford Journal of Legal Studies 16: 337-52.

(1997), 'Positively Fabulous: Why it is Good to be a Legal Positivist', The Canadian Jounal of Law and Jurisprudence 10: 231-48.

\& R. Cullen (1997), 'A Bill of Rights Odyssey for Australia: The Sirens are Calling', University of Queensland Law Joumal 19 (forthcoming).

Hart, H. (1994), The Concept of Law (2nd ed.), Clarendon Press, Oxford.

Howard, C. (1995), Interpretation of the Employment Contracts Act 1991, New Zealand Business Roundtable and New Zealand Employers Federation, Wellington.

Mandel, M. (1989), The Charter of Rights and the Legalization of Politics in Canada, Wall \& Thompson, Toronto. 
Smillie, J. (1994), 'The Allure of "Rights Talk": Baigent's Case in the Court of Appeal', Otago Law Review 8: 188-204.

— (1996), 'Formalism, Faimess and Efficiency: Civil Adjudication in New Zealand', New Zealand Law Review, Part 2: 254-74.

Waldron, J. (1992), 'The Irrelevance of Moral Objectivity', pp. 158-87 in R. George (ed.), Natural Law Theory, Clarendon Press, Oxford.

- (1994), 'Freeman's Defence of Judicial Review', Law and Philosophy 13: 27-42.

The author wishes to thank anonymous referees and the editor for their helpful comments.

\section{CLARIFICATION}

The note by Roger Hallam titled $A$ Vision of Trans-Tasman Cooperation, which was published in Agenda, volume 4, number 3, 1997, pages 365-370, was an edited version of a speech delivered at the Summer Sounds Symposium, Marlborough Sounds, New Zealand, 28 February - 2 March 1997. The Symposium was organised by Cognos Ltd. 